\title{
Митот за создавање на светот од телото на прасуштеството - компаративна анализа со акцент на примерите од Македонија
}

\author{
Аниела Грубер
}

Во фокусот на истражувањето се митовите за создавањето на светот од телото на некое прасуштество во кои разните негови телесни делови се врзуваат со настанокот на одделни космички елементи. Овој тип космогониски митови се јавува во бројни култури и тоа во разни географски подрачја на светот и разни историски периоди, проследени со одредени специфичности. Во нив убивањето или жртвувањето на ова суштество го реализираат разни ликови (од категоријата прв човек, културен херој итн.) кои се борат со чудовиштето, го убиваат и од деловите на неговото тело го градат светот. Транспонирањето на елементите во овие космогониски митови се одвива од сферата на микрокосмосот кон макрокосмосот. Аналогии се јавуваат во бројни примери од светската митологија, а воедно и од Балканскиот Полуостров. Целите на истражувањето се: откривање и реконструкција на локалните варијанти на посочените космогониски митови во народната книжевност од територијата на Македонија, при што акцентот ќе биде ставен на неговите манифестации во вербалниот медиум. Покрај тоа ќе бидат споменати и останатите негови медиумски манифестации - во ликовниот медиум и во обредните традиции проследено со нивно компарирање со соодветните варијанти во рамките на индоевропскиот ареал и пошироко. Преку компаративниот метод ќе бидат опфатени: дејствието, митските ликови, нивните функции, заемните односи, употребениот систем на симболи и метафори и.т.н., Истражувањето е конципирано интердисцплинарно со вклучување на граѓа, концепти и методолошки пристапи на повеќе научни дисциплини.

Клучни зборови: мит, космогонија, космогониски елементи, македонски фолклор, ламја, прасуштество, Св. Ѓорѓи, жртвување 


\section{1. Митови за настанокот на светот од телото на прасуштеството}

Варијантите на ова митско дејствие се мошне распространети во културите што припаѓаат на индоевропскиот ареал, но и во оние култури што според своето потекло не припаѓаат на овој јазичен и етнокултурен комплекс. Со цел да се стекне увид во истражуваното митско дејствие ќе претставиме некои од нив, а истите подоцна ќе бидат употребени како материјал во натамошните компарации.

1) Создавањето на светот од телото на Имир (скандинавска митологија). Ова дејствие е запишано во збирката Edda (Simek 2007: 7). Боговите Один, Вили и Ве го убиваат примордијалниот џин Имир и од неговото тело започнуваат да ги создаваат деловите на светот (Simrock 1876: 213-216). Актот на распарчување од страна на наведените митски ликови тука е претставен како процес на креативно создавање преку кој се уредува дотогашниот хаотичен свет, при што се создаваат небото, водите и другите природни елементи и феномени (Ross 1994: 156).

2) Мардук ја убива тијамат (вавилонска митологија). Во познатиот еп за создавањето на светот познат како Енума Елиш, Мардук ја убива Тијамат, го распарчува нејзиното тело и од неговите делови го создава односно го уредува светот (Lambert 2005: 565-602). Во митските дејствија и ликовните претстави таа е претставена како чудовишно зооантропоморфно суштество (некаде во вид на змеј или морска змија) со женски пол. Има карактер на симбол на примордијалните творечки сили, па дури и на целиот космос во неговата почетна - недефинирана форма (Eliade 1991: 64-67). ${ }^{1}$

3) Mumom за Пуруша (индиска митологија). Митот за Пуруша е запишан во Ригведа, древната индиска збирка на ведски санскритски химни (Mall 1982: 16). Прасуштеството Пуруша е поистоветено со светот, при што има мултиплицирани делови на телото (1000 глави, очи и нозе) и џиновски димензии, т.е. опишано е како екстремно високо така што ја опфаќа целата земја па и вселената (Geldner 1951: 187, 286). Овие обележја го вбројуваат Пуруша во ликовите застапници на слоевите на вселената. Боговите го жртвуваат и од неговото тело се создава т.е. уредува светот (Rig Veda 2019). И тука следува создавање на низа елементи од природата кои кореспондираат со деловите на неговото тело.

4) Mumom за Гајомард (иранска митологија). Во космолошките дејствија запишани во Бундахишн (во превод примордијално

\footnotetext{
${ }^{1}$ Ликовни претстави на Тијамат во вид на змеј или змија - Jacobsen 1968: 104-108.
} 
создавање), енциклопедиска збирка на космогониски и космолошки текстови создадени во средна Персија, претставено е настанувањето на светот како резултат на борбата меѓу доброто и злото односно Ахура Мазда (Ормазд) и Ариман (Hale 2008: 123). Ариман го испраќа демонот на смртта против синот на Ахура Мазда, Гајомард (Pakzad 2005: 58-66). Гајомард умира и од него се создаваат различни вредни елементи (олово, калај, стакло, сребро, злато итн.) поради што може да се заклучи дека и тој е една епифанија на микрокосмосот (Pakzad 2005: 109). Иранскиот мит за Гајомард може да се спореди и со митовите за Имир, Тијамат и Пуруша, при што е важно да се забележи дека, иако соодветствувањата на деловите од телото со појавите во светот кај овие примери не се идентични, станува збор за ист концепт во чија основа стои преобразбата на деловите од човековото тело во елементите од природата т.е. вселената. Космогониски мотиви се забележани и во еден пехлевски текст. Во него се говори како космосот се создава од некаков елемент што личи на огромен пламен и на чиста светлина. Овој пламен, настанат од Бесконечната светлина, бил сместен во тело во кое тој растел во период од 3000 години, за потоа од своето тело да ги создаде сите нешта. Според некои толкувања, станува збор за Ормазд, кој ја создава вселената од своето тело, а според други толкувања - некое друго двополово божество (Williams 1990: 72-76; Lajoye 2013: 36-38).

5) Преданија за создавањето на елементите на природата од телото на Гаргантуа (фолклорни традиции од Франција). Според овие преданија запишани во регионот на Нормандија, од тело на овој лик закопано под територијата на неколку локални општини настануваат некои делови на природата. Овие елементи кореспондираат со деловите на неговото тело (рид - глава, долина - врат, нозе - крајбрежје, стапала - планински венци итн.). Во овој случај отсуствува чинот на екслицитното распарчување на телото на овој лик. Постојат тврдења дека претставените содржини се нашле во француското народно творештво како резултат на скандинавската колонизација во Нормандија (Brunet 1889: 472, 473; Lajoye 2013: 31-33).

6) Траги на митот за „инверзниот Пуруша“ (традиции на средновековна Русија). Мотивот што е тема на нашата анализа може да се сретне и во традициите на словенските народи, но овој пат во една обратна варијанта, каде што човекот настанува од деловите на светот. Станува збор за апокрифниот текст Тајните на Енох или Словенски Eнох во кој светот е употребен за да се создаде првиот човек. Значи, во овој случај имаме создавање од макрокосмос кон микрокосмос, а не обратно (Lajoye 2013: 27-31). Деловите на телото на човекот се создадени од деловите на светот: неговото месо од земјата, крвта од 
росата и сонцето, очите од морето, коските од камењата, мозокот од движењето на ангелите и облаците, вените и косата од растенијата, а духот настанува од духот на Бог и од ветерот. ${ }^{2}$

7) Mumom за Пангу (кинеска митологија). Во енциклопедијата Тајпин јулан (10 век н.е.) се опишува како настанал Пангу, митски лик со џиновски димензии (Кюнстлер 1987: 36, 37). Во различните верзии на овој мит, Пангу е прапредокот а истовремено и демиургот од кој настанува светот. По неговата смрт, од деловите на неговото тело ќе се создадат елементите на вселената: од дишењето - ветер, од гласот - гром, од очите - сонце и месечина, од коски - камења и злато, од крвните садови - патишта, од крвта - сината и жолтата река итн. (Мелетински 2002: 247). ${ }^{3}$

8) Enот за Калевид (Естонија). Во епот се раскажува како овој лик заспива и сонува дека неговиот коњ е распарчен од волци. Таму каде што ќе падне коњот, од неговата крв ќе се создаде црвено езеро, од неговиот црн дроб - планина, од неговите коски - ридови, од неговите коси и гривата - растенија, а од опашката - грмушки (Kirby 1895: 59-60).

9) Muтот за божицата Атаенсик (народ Ирокези, Северна Америка). Атаенсик е божица на небото и прамајка што постоела пред сѐто друго. По нејзината смрт едниот од близнаците што таа ги родила ја создава вселената од нејзиното тело: од лицето - сонцето на небото, од градите - месечината и звездите, од другите делови - земјата (Црвенковска 2004: 137, 138).

10) Древномексикански космогониски мит. Демијурзите близнаци ја создаваат земјата во вид на божица чудовиште, а потоа ја преполовуваат на две и од долниот дел на нејзиното тело ја создаваат земјата, а од горниот дел небото. Од нејзините многубројни очи и усти се создаваат реките и пештерите, од носот и рамената - планините и долините додека од нејзините коси - дрвјата, цвеќињата и тревата (ЛеонПортилья 1977: 437, 438).

11) Мuтот за Хаинувела (Индонезија). Од телото на полубожеството Хаинувела излегуваат корисни растенија или животни (Jensen 1939).

\section{2. Општи обележја на митовите}

Преку споредбата на овие дејствија се доаѓа до одредени сличности и разлики меѓу нив. Така на пример, заедничко во митовите за Имир и Пуруша е тоа што телата на овие антропоморфни прасуш-

\footnotetext{
2 Дејствието е запишано кај Andersen 1983: 150.

${ }^{3}$ Неколку запишани варијанти на митот за Пангу: Lajoye 2013: 49, 50.
} 
тества се користат за создавање на светот. Но притоа се видливи и разлики, и тоа во карактерот на овој лик (праџин, прв човек, митски крал на луѓето), начинот на кој тој умира (жртвување, убиство, борба) и прашањето што или кој е создаден од деловите на неговото тело. Постојат ставови дека сличностите во сите овие митови се должат на нивното заедничко потекло (особено на индоевропското). На некакво заедничко потекло упатуваат и многубројните совпаѓања на деловите од телото на овие ликови и природните феномени што ќе се создадат од нив: месото и земјата, коските и карпите, крвта и водата, главата и небото, мозокот и облаците (Lincoln 1986: 1-3). Не смеат да останат незабележени и значителните разлики меѓу нив, а воедно и присуството на овој мит во традициите на Кина и Естонија што покажува дека тој ги надминува рамките на индоевропскиот етнокултурен ареал.

Особен проблем во науката е прашањето како истиот мотив се нашол во култури кои се толку различни и оддалечени меѓу себе во географска и хронолошка смисла. Дали е тоа резултат на интеркултурната комуникација меѓу разни култури што стапувале во заемни контакти преку миграции, соживот во мултикултурни општества или пак преку присилно наметнување на традициите на окупаторите врз окупираните етнички групи. Во рамките на вториот концепт решението се базира во архетипскиот карактер на овој мит т.е. неговата универзалност за човекот како вид, без разлика на културата и епохата во која егзистира. Според овој пристап, овие општости би се базирале на универзалните концепти на човековото перципирање на светот преку своето тело и поистоветувањето на себеси со околниот свет во кој тоа егзистира. Во основата на митовите за настанувањето на светот од телото на прасуштеството всушност стои идентификацијата на телото и околниот свет, која архаичната (митотворна) свест често ја сфаќа буквално, при што првиот елемент добива статус на микрокосмос, а вториот на макрокосмос.

Меѓутоа, целта на ова истражување не е да се даде одговор на прашањето на што се должи универзалноста на овој мотив, туку да даде придонес кон откривањето на неговите траги во фолклорот на еден конкретен етно-културен ареал - Македонија. Широката распространетост на посочените космогониски митови во разни историски периоди и географски подрачја овозможува да се спроведе компаративна анализа, која може да се даде и придонес во откривањето на овие траги и определувањето на нивното изворно значење.

Во поголемиот дел од дејствијата кои беа компактно претставени во претходната глава може да се забележи дека услов за да се создаде светот или неговите суштински елементи е нечија смрт. Во сканди- 
навската митологија тоа е Имир (првото антропоморфно суштество - џин), во ведската митологија Пуруша (првиот човек), а во кинеската митологија Пангу (исто така прв човек), во вавилонската Тијамат итн. Траги од ова дејствие може да се сретнат и во древнохеленските традиции околу ликот на Горгона-Медуза, како и во словенските, околу самовилите и ламјата. Во секој од посочените митови убивањето или жртвувањето на ова суштество го реализираат разни ликови. Некаде станува збор за јунак кој носи карактеристики на т.н. културен херој или пак прв човек што се бори со ова прасуштество (неретко со предзнак на чудовиште), го убива и од деловите на неговото тело го гради светот (Чаусидис 2005: 263).

Од претходно посочените дејствија можеме да забележиме уште некои други универзални обележја кои важат за повеќето или за сите нив. Токму тие ќе ни послужат во понатамошните компарации со дејствијата од Македонија. Овие карактеристики ќе ги расчлениме на две нивоа:

a) Ниво на ликови кои се транспонираат во новосоздадениот свет: ликови од женски пол, влекачи (змијолики животни), поврзани со вода (долно ниво на вселената), симболи на хаосот (деструктивното и негативното), со џиновски размери, со мултиплицирани делови на телото.

б) Ниво на елементи и дејствија: двобој (борба) со машки лик, поделување на два дела или распарчување, транспонирање на делови од телото во елементи од природата.

\section{3. Св. Ѓорѓи ја убива ламјата}

Космогониските мотиви од типот распарчување на чудовиштето и создавање на деловите на светот од неговото тело, може да се сретнат и во фоклорните традиции од Балканскиот Полуостров, а меѓу другото и во Македонија. Судејќи според елементите содржани во нив, тие можат да се сметаат за манифестации на основниот космогониски мит за создавањето на светот од телото на прасуштеството.

Во примерите од овие територии е застапено сижето за убивањето и распарчувањето на некое чудовиште од страна на јунакот демијург. Чудовиштето што е убиено припаѓа на следните категории митски суштества: змеј, ламја, аждер, јуда, самовила (Стојановиќ-Лафазановска 2001: 311). ${ }^{4}$ Потоа следува создавањето на одредени еле-

\footnotetext{
${ }^{4}$ Тука види подетално и за херојската иницијација во македонската народна книжевност.
} 
менти на космосот (вода, други течности, растенија, жито итн.) од некои делови од неговото тело.

Елементите на овој мит се присутни во дејствието за борбата на Св. Ѓрѓ́ со ламјата. На Балканскиот Полуостров тоа е евидентирано во Македонија, Србија и Бугарија, каде што, освен Св. Ѓор́́ , против ламјата се борат и други локални херои или светци. Мотивот за борбата на Св. Ѓорѓ и Св. Илија со ламјата, во Македонија е запишан од страна на Миладиновци во 1861 г., и од Миладиновић (за јунакот и ламјата) во 1920 г. ${ }^{5}$ Освен во Македонија, тој може да се сретне и во неколку прилози од Сборникъ за народни умотворения објавуван во Бугарија, а запишани од неколку автори. ${ }^{6}$

Од дејствијата за борбата со чудовиштето подетално ќе анализираме една песна за Св. Ѓрѓ́ и ламјата што е евидентирана во неколку збирки и публикации. Една од нив се наоѓа во Архивот на Институтот за фолклор „Марко Цепенков“ во Скопје (у даљем тексту: АИФ), а е снимена во 1969 година во Пробиштипско.

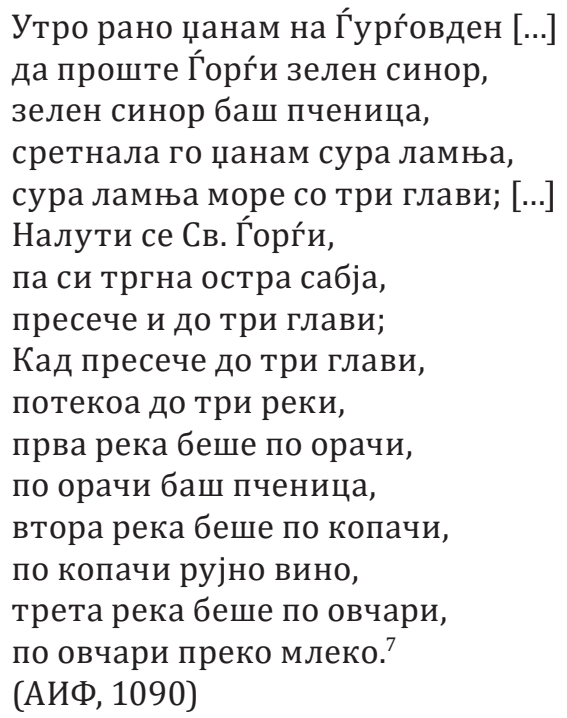

\footnotetext{
${ }^{5}$ Миладиновци 1962: за Св. Ѓорѓи, песна бр. 35, 38, за Св. Илија песна бр.40; Миладиновић 1920: 162, 431.

${ }^{6}$ Во Сборник за народни умотворения, наука и книжнина (у даљем тексту: СбНУ): Волчинов за Бранко јунак: СбНУ II, 1890: песна бр. 6, 20-21; Верковиќ за Мирчо Војвода: СбНУ X, 1894: песна бр. 6, 9; Јастребов во СбНУ XVI-XVII, 1900: песна бр. 4, 15; Кузов за Св. Ѓорѓи и ламјата во истата книга, песна бр. 3, 54.

${ }^{7}$ АИФ, лента бр. 1090 (снимил Стеван Петров во 1969 г.). Во уште една верзија, запишана кај Целакоски, од пресечената ламја излегуваат пченица, рујно вино и јагниња (Целакоски 1984: 199-200).
} 
Во ова дејствие, како противник на јунакот Св. Ѓорѓ се јавува ламјата, која му го попречува патот и воспоставува контрола врз водите. Јунакот ја убива ламјата и од нејзините глави протекуваат три реки што содржат течности важни за човековата егзистенција (жито, вино и млеко): „прва река беше по орачи, / по орачи баш пченица, / втора река беше по копачи, / по копачи рујно вино, / трета река беше по овчари, / по овчари преко млеко“.

Во овие песни се присутни (експлицитно или имплицитно) следниве елементи и дејствија: ламјата ја грабнува и заробува водата како симбол на егзистенцијата, плодноста и животот; Св. Ѓорѓ и (херојот) се бори со чудовиштето; убивање на чудовиштето (сечење на делови на неговото тело); ослободување на водите; содавање корисни добра од деловите на телото на чудовиштето.

Освен во народната книжевност, овој мотив во Македонија е чест и во визуелниот медиум, во рамките на средновековниот и преродбенскиот живопис. Станува збор за сцени изведени во вид на фрескокомпозиции или икони настанати во рамките на култот на Св. Ѓор́́ кој бил мошне популарен на овој регион. Во нив светецот е прикажан како воин и војвода, кој, качен на бел коњ, ја убива ламјата т.е. аждајата. Овие сцени се особено присутни во црквите и манастирите посветени на Св. Ѓорѓи (Луческа 2010: 137). ${ }^{8}$

На Балканот овој мотив може да се идентификува и во едно обредно дејствие. Станува збор за празникот Бадник и обредното горење на бадниковото дрво во домашното огниште што се изведува за овој празник. Бадниковото дрво се сече, се внесува дома и се пали. Освен тоа, дрвото се мачка со мед, се посипува со жито, се дупчи и во дупката се налеваат вино, мед и масло, а се ставаат и жито и разни други зрна. Според анализите на Иванов и Топоров, палењето на бадникот претставува чин на симболично горење (жртвување) на митскиот змеј. Овој чин може да се третира како космогониски и тоа поради времето во кое се изведува - пред Нова година, што упатува на заклучокот дека тој изворно се поклопувал со крајот на годината и почетокот на новиот циклус кога всушност се повторува чинот на создавањето на светот. Доколку дрвото се поистовети со митскиот змеј што е жртвуван (изгорен), како што тоа го прават посочените автори преку идентификувањето на Бадник со ведскиот змеј Ahi Budhnya

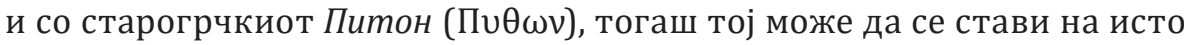

\footnotetext{
${ }^{8}$ Како примери ќе ги посочиме фрескокомпозицијата во црквата Св. Ѓорѓи во с. Старо Нагоричане, Куманово која датира од 14 век (Serafimova 2008: 66) и иконата Св. Ѓорѓи убива змеј во црквата Св. Ѓорѓи во Струга која датира од третата четвртина на 14 век (Поповска-Коробар 2008-2009: 297).
} 
рамниште со ламјата од наведените преданија, која е исто така убиена (Иванов и Топоров 1974: 37-38; Чаусидис 2005: 263-265). На ова рамниште ќе забележиме сличности и во поглед на елементите што се ставени во контакт со бадниковото дрво (вино, мед, масло, жито) пред тоа да биде запалено (жртва). Се работи токму за истите елементи што во претходните примери истекуваат од телото на ламјата.

\section{4. Космогониски аспекти на дејствието}

Некои од досегашните истражувачи на овие сижеа забележуваат во нив одредени елементи и дејствија со космогониски предзнак (ликови, природни елементи итн.). На ова место ќе се задржиме само на космогониското дејствие што се однесува на убивањето на чудовиштето и повторното воспоставување на космичката рамнотежа. Македонските примери на овој мотив се анализирани од страна на СтојановиќЛафазановска, и тоа во рамките на митот за културниот херој (Стојановиќ-Лафазановска 2001), како и од Анастасова-Шкрињариќ, во рамките на темата за змејоборството (Анастасова-Шкрињариќ 2011).

Стојановиќ-Лафазановска го анализира ова сиже како иницијациска борба со чудовиштето, со цел да се придобијат културните и природните добра што се симбол на благосостојбата (вода, вино, жито, мед, масло итн.) (Стојановиќ-Лафазановска 2001: 356). Притоа таа се повикува на Топоров, според кој ваквиот чин на жртвување (обично присутен во сижеата што се однесуваат на Св. Ѓор́́ ) е поврзан со распарчувањето на sверот. Станува збор за завршното дејствие со кое се воспоставуваат новото време и новата животна сила (Топоров 1992: 20; Стојановиќ-Лафазановска 2001: 357).

Според Анастасова-Шкрињариќ, убивањето на чудовиштето и ослободувањето на водите помагаат во одржувањето на космичката рамнотежа, при што овие дејствија соодветствуваат на универзалниот космогониски мит во кој митскиот херој ја остварува креацијата на вселената преку космогонискиот дуел со ова митско суштество (Анастасова-Шкрињариќ 2011: 170). Имено, борбата со змеј (ламја, ала, аждаја) за враќање на водната рамнотежа, која, како што забележавме, има космогониски карактер, е воедно и една од митологемите на космогонискиот мит за воспоставувањето на космосот од примордијалниот хаос (Анастасова-Шкрињариќ 2011: 173-174). Легендата за убивањето на ламјата од страна на Св. Ѓорѓ има универзален карактер. Ова митско дејствие е широко распространето, при што најчесто е поврзано со конкретни места и градови (еден таков пример се однесува на Кирена (Cyrene) во денешна Либија), Анастасова-Шкрињариќ 2011: 160, 167). 
Космогонискиот мотив за победата над хаосот и воспоставувањето на редот (новата сила, новата година) или уредувањето на космосот се остварува преку распарчувањето на чудовиштето и создавањето на елементите на природата (т.е. материјалните добра) од неговото тело. Во ваквиот чин на распарчување имаме транспонирање на дел од неговото тело во космичките елементи. Во конкретните случаи главите се преобразуваат во реки, или поконкретно првата глава во жито (река од жито), втората во вино (река од вино), а третата во млеко (река од млеко), а кај некои варијанти во мед и/или во масло. Со тоа телото на чудовиштето се поистоветува со космосот и се транспонира во насоката од микрокосмос кон макрокосмос.

Исто така, одделните елементи што ги среќаваме во посочените примери, поточно херојот, непријателот (чудовиште), природните добра итн., се директно поврзани со дејствијата што имаат космогониски карактер. Притоа мошне јасно може да се воочи и космичкиот карактер на учесниците т.е. ликовите, што ќе биде цел на наредната анализа. Поконкретно, станува збор за космичките обележја на ликот на ламјата и херојот.

\section{5. Космички обележја на ликовите}

\section{1. Ламја}

Дејствијата што ги наведовме или обработивме како аналогии покажуваат дека во народните верувања и фолклорот на Балканскиот Полуостров (конкретно кај Македонците, Србите и Бугарите) постои митско суштество - ламја, именувано со неколку различни називи: ала, аждер, аждаја итн. (Вражиновски 1998: 161).

Потеклото на едниот од називите за ова митско суштество, поточно аждер и аждаја, се поврзува со змејовидниот Ажи-Дахака, познат од зороастријските текстови на древните Персијци (АнастасоваШкрињариќ 2011: 158). Постојат претпоставки дека е донесен на Балканот во доцниот среден век со посредство на Турците (и на турскиот јазик) и дека од традициите околу овој митски лик потекнуваат јужнословенските називи аждер и аждаја. Ажи-Дахака е претставен како човекојадец во вид на триглава змија и како противник на богот на огнот (Чаусидис 2005: 213-214).

Од особено значење за нашево истражување е класифицирањето во неколку категории на претставите за овој лик во Македонија, и тоа според неколку негови карактеристики и значења. 


\subsection{1. Ламјата како симбол за хаосот - деструктивните сили}

Како змијолика господарка на подземниот свет, алата се поврзува со вештерката и врколакот (во хрватските народни традиции) и со руската Баба Јага, која покажува релации со постарите претстави на женските демонски суштества (Раденковић 1982: 11-16). Без да навлегуваме натаму во симболиката на овие ликови, ќе забележиме само дека сите тие имаат еден заеднички белег односно претставници се на деструктивните сили или хаосот.

Ламјата во балканските народни традиции има исклучиво негативни карактеристики и функции поврзани со предизвикувањето разни несреќи на луѓето: таа го нарушува водниот баланс (предизвикува суша) и ги уништува посевите (Анастасова-Шкрињариќ 2011: 158-159; Вражиновски 1998: 190; Георгиева 1983: 122). Очевидна е нејзината непријателска функција бидејќ и го уништува плодородието - најважната компонента што луѓето ги одржува во живот.

\subsection{2. Ламјата како симбол на водните пространства т.е. долните нивоа на космосот}

Во балканските традиции овој лик е поврзан со одредени елементи од природата (вода, ветер, бура, градоносни облаци), а обично престојува покрај водните површини како што се езерата, морињата и реките (Анастасова-Шкрињариќ 2011: 158-159; Вражиновски 1998: 190; Георгиева 1983: 122).

Во Македонија се среќаваат верувања за ламјата што живее околу Охридското и Преспанското Езеро. Овие верувања биле предмет на истражување на Лафазановски, кој забележува дека во македонските народни легенди и во збирките на народни умотворби се среќаваат примери што даваат можности за претпоставка дека кај жителите на населените места околу Охридското Езеро било мошне фреквентно традиционалното верување за постоењето на езерско чудовиште ламја. Ова верување го прави автентично самата претпоставка дека ламјата живее токму во Охридското Езеро (Лафазановски 2006).

Уште една претстава за ламјата поврзана со водните површини може да се сретне во варијантата на Димо Стенковски во која ламјата живее околу едно дрво никнато насреде езерото. Според Лафазановски, се работи за универзални елементи типични за космогониските митови во кои езерото го застапува првобитниот океан, додека дрвото среде езерото - космичкото дрво како симбол на центарот на светот. И ламјата од нашиот пример е дел од еден космогониски амбиент прису- 
тен во голем број примери од светските традиции. Иако на прв поглед се чини дека таа во случајов го заменува „божеството што создава“, на ваквиот заклучок му противречат нејзините доминантни демонски (во принцип негативни) карактеристики (Лафазановски 2006: 28).

Освен со водата, ламјата е поврзана и со земјата, која исто така спаѓа во долните нивоа на вселената. На нејзината релација со земјата, покрај другото, може да упатува и сличноста на двата словенски збора што ги означуваат - змија и земја, а некои научници сметаат дека оваа сличност може да се должи и на нивната некогашна еквивалентност (Чаусидис 2005: 222).

Поврзаноста на змијата со водните пространства и со земниот слој на вселената е присутна кај многу народи. Таква е претставата за змијата што го одржува космичкиот ред така што ја обвива земјата со своето тело и ја држи за да не се распука од тежина, при што и ја отпива водата во која лежи, спречувајќи таа да се разлее и да настане космички потоп. Оваа „космичка змија“ всушност се изедначува со океанот што ја обиколува земјата (Чаусидис 2005: 211; Анастасова-Шкрињариќ 2008: 117-118).

Еден таков пример е приказната Царскиот син и ѓаволот, запишана во збирката на Шапкарев, во која, во рамките на локалното верување за ламјата, може да се забележат и општите белези на овој универзален митски мотив. Ламјата (езерското чудовиште) е претставена како голема змија што го држи езерото обиколено, а главата и опашката ѝ биле собрани една со друга, што одговара на добропознатиот Уроборос, митската змија што си ја гризе сопствената опашка (Шапкарев 1976: 182 според Лафазановски 2006: 25).

\subsection{3. Ламјата како многуглаво суштество со големи димензии}

Во народните традиции на Македонија, Србија и Бугарија ламјата се претставува како многуглаво суштество со големи димензии, а според некои верувања и како „главатар на змиите“. ${ }^{9}$ Бројот на нејзините глави е различен: три, седум, девет, четиринаесет (Вражиновски 1998: 190). Други мултиплицирани делови на нејзиното тело може да бидат и опашките, шепите и крилјата. Тоа може да го забележиме во примери од Бугарија, каде што бројот на нејзините крилја е шест, а има ламји и со дванаесет опашки (Георгиева 1983: 118).

\footnotetext{
9 За троглавата ламја кај Србите: Раденковић 1982: 97; кај Бугарите: Георгиева 1983: 118; кај Македонците: Вражиновски I 1998: 188-190; Вражиновски 1995: 47, 48; Лафазановски 2006: 27.
} 


\subsection{4. Ламјата како панкосмички змеј}

Категоријата митски ликови наречена панкосмички змеј ќе се покаже како мошне важна за космичките обележја на нашата ламја. Фигурата на овие митски ликови, согледана од космолошки аспект во себе ги создржи трите слоеви на универзумот изразени преку компонентите на нејзиното тело и нивното значење: заден дел (змиска или рибина опашка и крлушки) како репрезент на долниот дел од вселената; гради, предни нозе и глава (сувоземни цицачи) - надземно ниво; птичји крилја и пердуви - горен дел на вселената. Или поконкретно: риба и змија - подземје, цицачи - надземје, птици - небо (Чаусидис 2005: 217). ${ }^{10}$

Кај ваквите надреални хибридни митски ликови главно доминираат белезите на змијата, а мошне често се застапени и рибата, гуштерот и цицачите (волк, коњ, куче, мечка итн.). Освен тоа, овие митски ликови имаат и други митски белези: џиновски димензии, мултиплицирани делови на тело и негативен т.е. чудовиштен предзнак (Чаусидис 2005: 212-213).

Истите белези ќе ги согледаме и во надворешниот опис на нашата ламја. Освен претходно споменатата џиновска големина, мултиплицираните делови на нејзиното тело и негативните карактеристики, во нејзиниот изглед партиципираат неколку видови животни од кои главно доминираат змијата т.е. змејот. ${ }^{11}$ Таа се замислува како животно со долга опашка, телото ѝ е покриено со рибни крлушки, има четири нозе, главата и е слична на коњската или кучешката (уште се нарекува и „кучка ламја“), а покрај тоа има и голема вилица, заби, јазик и крилја (Вражиновски 1998: 190, 192). Според тоа, ламјата ги содржи трите космички слоеви и тоа преку нивните зооморфни репрезенти. Тука ги имаме предвид различните животни: змија, риба (змиско тело, змиска или рибина опашка, рибни крлушки) како долно ниво на вселената т.е. подземје; куче, коњ (нозе, кучешка и коњска глава) како средно ниво т.е. надземје; птици (крилја, пердуви, клун) како горно ниво т.е. небо. Ваквите обележја упатуваат на Панкосмичкиот змеј како парадигма на ликот на ламјата од Балканските простори.

Суштества од типот панкосмички змеј често се поставени вертикално со цел ниовното издолжено трочлено хибридно тело поувер-

\footnotetext{
10 За симболизацијата на вселената по пат на зооморфизација т.е. употреба на животни како претставници на трите нивоа на вселената во кои тие и реално егзистираат: Чаусидис 2005: 209.

${ }^{11}$ Се сметало дека ламјата настанува од смокови или змејови кои ќе доживеат поголема возраст.
} 
ливо да се изедначи со космичката оска и трите зони на космосот. Ова може да се воочи во неколку митологеми, меѓу кои Чаусидис ги вбројува и преданијата од балканскиот фолклор во кои змејот (алата, ламјата) ја пие водата од земјата и ја носи на небото што сведочи за нејзината вертикална положба и улогата на медијатор на водите во вселената (Чаусидис 2005: 217).

Митскиот лик со карактер на панкосмички змеј може да се препознае и кај примордијалните суштества од чие тело ќе биде создаден светот. Чинот на транспонирање на нивното тело во космос имплицира и на нивното директно поистоветување со него. Карактерот на панкосмички змеј Чаусидис го забележува и кај акадската Тијамат, феникискиот Левијатан, старокинескиот Пангу и др. (Чаусидис 2005: 217). Во оваа категорија може да се вклучи и ламјата од дејствието што тука го обработуваме. Како што веќе забележавме, на нејзината фигура се исто така забележливи и карактеристики на Панкосмичкиот змеј со што таа се доближува до останатите примордијални суштества од чие тело ќе биде создаден светот.

\section{2. Хepoj}

Во горепретставеното митско дејствие, ликот на Св. Ѓорѓ се појавува во улога на спасител и заштитник на луѓето и симбол за позитивните космички сили. Ваквата функција, освен кај христијанските светци, се забележува и кај други ликови од јужнословенските традиции кои ги штитат луѓето од злото или од некои конкретни негативни ликови (најчесто чудовишта) што им предизвикуваат разни штети. Со текот на времето оваа улога се менувала односно им била доделувана на различни ликови, почнувајќи од змејовите, па сѐ до разните локални херои и светци. Сепак, независно од тоа дали станува збор за херој, светец, змеј или некој друг лик, сите тие во својата основа содржат едни исти функции, а тоа е заштитата на одреден регион и застапување на позитивното начело. Во нивните обележја (обработени во наредните потпоглавја) се забележува дека заштитничката улога на овие ликови е придружена од огнениот елемент (гром, светлина, сонце), така што сите нив можеме да ги третираме и како слоеви присутни во ликот на нашиот херој. Притоа е можна и обратната релација - расчленување на нашиот херој на следните категории ликови: змеј, громовник (Перун), епски херои и христијански светци. 


\subsection{1. Змеј}

Во верувањата и другите народни традиции од Македонија и останатите јужнословенски региони змејот пред сѐ има улога на заштитник. Секоја земја, област, па дури и секое село, има свој змеј (покровител, бранител, заштитник) што го штити дадениот регион од разни негативни фактори, најчесто претствени преку ламјата или пак преку друг змеј - застапник на некој соседен регион. Оваа функција се реализира така што тој заспива, при што неговата душа излегува од телото и се бори со непријателите (Вражиновски 1998: 185).

Заштитничката улога на змејот е поврзана со змијата, која на Балканот била отсекогаш почитувана како чувар-заштитник и тоа првобитно во однос на водата, а подоцна и на разните подземни и надземни богатства. Во Македонија се верувало дека секое место (извор, лозје, нива или куќа) има сопствена змија - стопан. Култот кон неа се негувал и во други средини, кај останатите словенски, индоевропски и неиндоевропски народи: Јужни Словени, Белоруси, Руси, Чеси, Словаци, Романци, Молдавци, Грци, Албанци, Италијани, Французи, Англичани, Швајцарци, Турци и др. (Анастасова-Шкрињариќ 2011: 139-140; Zelenin 1927: 386). Во сите овие традиции може јасно да се препознае нејзината улога на чувар на универзумот и тоа не само преку обиколувањето на земјата и спречувањето на нејзиното распукување, туку и преку чувањето на одреден регион или на некоја друга конкретна компонента поврзана со животот и егзистенцијата на луѓето.

Со текот на времето претставите за змејот и неговите функции ќе се менуваат така што и овој архаичен лик ќе биде дополнуван со нови карактеристики. Натаму ќе следува негово постепено заменување со земски ликови, главно претставени преку реални историски личности (војводи и војсководачи, како што се Марко Крале и Гоце Делчев) на кои дури ќе им се припишува и змејско потекло, така што тие постепено ќе се претворат во епски херои. Во јужнословенската народна култура ликот на змејот е поврзан и со светците и тоа како помошник на Св. Илија во неговите борби со ламјата. Притоа змејот е оној што фрла по неа со огнени стрели, од кои на небото се создаваат светкавиците и громотевиците (Вражиновски 1998: 179, 186, 187). Оваа функција змејот ја има и независно од присуството на Св. Илија, што упатува на неговата изворна огнена природа, а веројатно и со релациите со словенскиот бог-громовник (Перун). Во евроазискиот ареал се присутни многу други божества кои имаат ваква огнена природа т.е. фигурираат како владетели на громотевиците и на молњите (последниве третирани како „небески оган“) (Георгиева 1983: 120). Вакви карактеристики поседуваат боговите-громовници од типот на Зевс, Јупитер, Тор, Донар, 
Индра, Перун, па дури и фолклоризираниот Св. Илија, и разните епски херои.

\subsection{2. Громовник (Перун)}

Големите празнини во нашите сознанија за карактерот и функциите словенските пагански божества организацијата на словенскиот пантеон оневозможува целосно и објективно реконструирање на ликот на Перун. Според Топоров, овие непознаници го оневозможуваат и увидот во хиерархијата и меѓусебните врски на боговите. Сепак одредени анализи и сведоштва овозможуваат реконструирање во најопшти црти на некои карактеристики на прасловенските богови почитувани кај сите Словени или кај дел од нив. Во нив со голем степен на сигурност можат да се вклучат боговите Перун и Велес/Волос кои се воедно вклучени и во едно заедничко митско сиже за нивниот двобој и победата на Перун над Велес. Во ова сиже богот Велес се поврзува со хтонскиот змеј (сличен по име на ведскиот хтонски лик Вала), како и со ламјата и аждајата од јужнословенските традиции. Според досегашните реконструкции постои можност водечката улога во ова сиже да му се припише на Перун, кој се сметал за првиот и надмоќниот меѓу боговите. Засега нема сигурни факти кои би упатување на Перун како врховен бог со „монотеистички претензии“ (Топоров 2001: 28-31). ${ }^{12}$ Иако не може да се тврди со сигурност кај кои словенски народи и во која мера се почитувал овој бог, на Балканот може да се најдат голем број остатоци кои укажуваат на култот кон ова божество. Станува збор за топонимии со неговото име кои можат да се сретнат и на територијата на Македонија (кумановско, мариовско итн.) (Чаусидис 1994: 428, 445).

Огнената и заштитничката улога на Перун можеме да ја потврдиме со народните преданија од Русија и Балканот каде што тој е претставен како крилест змеј. Неговата функција се состои во борбата против змијоликите суштества кои се инкарнација на злото. Тука треба да се наведе една опозиција што се среќава кај Јужните Словени: Перун - небесна сфера, светлина, во опозиција на митски суштества, претставници на хтонските предели. Од ваквите претстави за Перун можеме да дојдеме до заклучок дека змејот е всушност негова животинска инкарнација (Чаусидис 1994: 414).

\footnotetext{
12 За космогонискиот карактер на борбата меѓу Перун и Велес: Анастасова-Шкрињариќ 2011: 181; за хтонската природа на Вала: Чаусидис 2005: 215.
} 
Врската на Перун со громот и молњата е реконструирана со помош на некои конкретни фоклорни традиции. Таков пример е една белоруска бајка во која Перун победува со молња и гром (Топоров 2001: 29). Ваквата претстава за Перун може да се потврди и со податоците од народните преданија во кои тој се движи по небото во кочија придружуван од громови (тресокот од неговата кочија) и молњи (неговите стрели). Оваа слика Чаусидис ја поистоветува со Тор и Индра од Едските и Ригведските химни. Во фолклорот на Источните и Јужните Словени како аналогна претстава на Перун може да се земе Св. Илија, кој во одредена смила може да се смета и за продукт на словенскиот пагански громовник (Чаусидис 1994: 416-418). Истото е потврдено и од Топоров според кој ваквиот карактер на Перун преминува на Св. Илија, кој се смета за негов христијански наследник. Во фолклорот во Македонија, Србија и Бугарија постојат верувања дека Св. Илија се бори против алите во придружба на змејовитото дете (Зечевић 1981: 64, 71; Георгиева 1983: 83; Чаусидис 1994: 439, 440).

\subsection{3. Христијански светци}

Процесот на христијанизирање на словенските земји, кој траел од VII до XII в. ги опфатил и боговите т.е. идолите во кои дотогаш се верувало. Дел од нив отишле во целосен заборав или биле демонизирани и преобразени во непријатели на човекот, додека пак други ги задржале своите елементи при што нивните имиња биле заменети со имињата на некои христијански светци како што се Св. Илија, Св. Ѓорѓи, Св. Никола, Св. Власија и др. (Топоров 2001: 32, 33).

Во науката постои согласност дека ликот на громовникот продолжува да живее во фолклорот на Јужните Словени и тоа, персонализиран во два одделни ликови: Св. Илија (покровител на громот) и Огнена Марија (покровителка на молњата), која е прикажана и како негова сестра (Чаусидис 1994: 418). Покрај другите карактеристиките на громовник, Св. Илија е и борец против ламјата (хтонското змијолико суштество) што претставува уште едно рамниште на кое тој се поистоветува со змејот и со Перун.

Освен кај Св. Илија, функциите на Перун можат да се ги препознаат и кај Св. Ѓорѓи, кој е исто така покорувач на змејот односно ламјата. Вражиновски согледува и можно мешање на нивните функции, така што во некои случаи Св. Ѓоѓ́ се јавува како владетел на громот, а Св. Илија како покорувач на чудовиштето (Вражиновски 1998: 245). Покрај овие два светци, со демонот се борат и Св. Тодор и Св. Никола, на кои исто така им се припишуваат обележја на змеј што се судира 
со демонот, кој во конкретниот случај сака да ги потопи бродовите (Георгиева 1983: 130). Во ликот на Св. Никола можат да се препознаат функциите на Велес, земајќи ја предвид врската на двата лика со водата и тоа на Велес како бог што престојува во земските води и на Св. Никола како нивни светец-заштитник (Вражиновски 1998: 245).

Ваквата замена т.е. идентификација на Перун со Св. Илија и со Св. Ѓорѓи, а на Велес со Св. Никола (и со Св. Василиј) ја покажува неможноста за потполно издвојување на светците од паганската религија на Словените, поради што на нив се префрлаат се префрлаат главните обележја и функции на нивните некогашни пагански претходници. Се покажува дека старите словенски божества во одредена смисла никогаш и не биле заборавени, така што нивните традиции се прелеале во народните верувања и обреди, при што теонимите на боговите биле заменети со имињата на новите христијански свети ликови. Преку овој процес и светците многу ќе се оддалечат од својот изворен христијански протомодел (присутен во житијата и апокрифните текстови) и поминувајќи низ процес на секундарна митологизација ќе добијат натприродни магиски особини и власт над природните појави и животот на човекот (Вражиновски 1998: 245).

Сево ова покажува дека зад ликот на херојот од нашето дејствие стои заштитникот на луѓето и оној што им обезбедува живот (претставник на доброто начело). Во него, под христијанскиот пласт, можат да се забележат различни слоеви од поранешните верувања. Без разлика дали станува збор за змеј, епски херој, Перун, Св. Илија или Св. Ѓорѓи, на функционално ниво се работи за едни исти ликови.

\section{6. Компаративна анализа на ликовите, елементите и дејствијата}

Досегашните обележја на парот спротивставени митски ликови (ламјата, Св. Ѓорѓ и другите негови еквиваленти) ни овозможуваат да дојдеме до следните сознанија. Ликот на Св. Ѓорѓ (или Перун, змејот, Св. Илија и др.) има улога на бранител, заштитник, но и создавач т.е. уредувач на космосот (демијург). Тој е симбол на редот, на конструктивните сили и на позитивниот принцип. Од друга страна, ликот на ламјата (алата или другите слични на неа демонски суштества) има улога на непријател, напаѓач и заробувач што воедно фигурира и како симбол за хаосот, на примордијалниот (првобитниот т.е. неуредениот) космос, како и на деструктивните сили и негативниот принцип. 
Посочените карактеристики на двата главни лика, му даваат на нашето главно дејствие карактер на космогониска борба што се случува пред создавањето на „овој свет“ т.е. пред почетокот на „ова време“ коешто воедно покажува заеднички карактеристики со слични традиции од балканскиот и индоевропскиот ареал, па и пошироко. Покрај тоа, во овие традиции се содржани и други заеднички ликови и дејствија кои ќе бидат нотирани при компаративните анализи што следуваат.

Како аналогии на ламјата можат да се наведат голем број жртвувани митски ликови чие што тело се транспонира во разни макрокосмички елементи: Имир, Тијамат, Пуруша, Гајомард и други, додека пак од Балканските аналогии можат да се наведат жељинската ала од Србија и митската змија од Бугарија. ${ }^{13}$

\begin{tabular}{|c|c|c|c|}
\hline Женски лик & $\begin{array}{c}\text { Влекач } \\
\text { (змијолико } \\
\text { животно) } \\
\end{array}$ & $\begin{array}{c}\text { Вода (долен слој } \\
\text { на вселена) }\end{array}$ & $\begin{array}{c}\text { Деструктивност, зло, } \\
\text { хаос }\end{array}$ \\
\hline $\begin{array}{l}\text { ламја, ала, змија } \\
\text { Тијамат } \\
\text { Имир (хермафродит) } \\
\text { Атаениск } \\
\text { лик од древномекс. мит }\end{array}$ & $\begin{array}{l}\text { ламја, ала, } \\
\text { змија } \\
\text { Тијамат } \\
\text { Вритра }\end{array}$ & $\begin{array}{l}\text { ламја, ала, змија } \\
\text { Тијамат } \\
\text { Имир (настанува од вода) } \\
\text { Атаениск } \\
\text { лик од древномекс. мит } \\
\end{array}$ & $\begin{array}{l}\text { ламја, ала, змија } \\
\text { Тијамат } \\
\text { Вритра } \\
\text { лик од древномекс. мит }\end{array}$ \\
\hline $\begin{array}{l}\text { Џиновска } \\
\text { големина }\end{array}$ & \multicolumn{2}{|c|}{ Мултиплицирани делови на тело } & $\begin{array}{c}\text { Машки демијург (херој, } \\
\text { светец, божество) }\end{array}$ \\
\hline $\begin{array}{l}\text { ламја, ала, змија } \\
\text { Тијамат } \\
\text { Пуруша } \\
\text { Ормазд, Гајомард } \\
\text { Имир } \\
\text { Гаргантуа } \\
\text { Пангу }\end{array}$ & \multicolumn{2}{|c|}{$\begin{array}{l}\text { ламја, змија } \\
\text { Тијамат } \\
\text { Пуруша } \\
\text { Имир (можно е да се двајца) } \\
\text { лик од древномекс. мит }\end{array}$} & $\begin{array}{l}\text { ламја, ала, змија } \\
\text { Тијамат } \\
\text { Пуруша } \\
\text { Гајомард } \\
\text { Имир } \\
\text { лик од древномекс. мит }\end{array}$ \\
\hline
\end{tabular}

Табела 1: Компаративна анализа на ликови

\footnotetext{
${ }^{13}$ Трите реки од езерото на Жељин во Србија (Расина, Коњска и Предолска) истекуваат од крвта на убиената ала (Тодоровић 2011: 214). Исто така, во коледарските песни за Бранко јунак, тој ја бара и ја убива ламјата - змијата со три глави, повеќе крилја и опашки при што од неа истекува млеко (Георгиева 1983: 118).
} 


\begin{tabular}{|c|c|c|c|}
\hline $\begin{array}{c}\text { Поделување на два дела, } \\
\text { распарчување }\end{array}$ & Глава (очи) - води & $\begin{array}{c}\text { Глава (коса) - } \\
\text { растенија }\end{array}$ & $\begin{array}{l}\text { Стомак } \\
\text { - води }\end{array}$ \\
\hline $\begin{array}{l}\text { ламја, ала, змија } \\
\text { Тијамат } \\
\text { Имир } \\
\text { Пуруша } \\
\text { лик од древномекс. мит }\end{array}$ & $\begin{array}{l}\text { ламја, ала, змија } \\
\text { Тијамат } \\
\text { Ормазд } \\
\text { Енох } \\
\text { лик од древномекс. мит }\end{array}$ & $\begin{array}{l}\text { ламја, змија } \\
\text { Имир } \\
\text { Ормазд } \\
\text { Енох } \\
\text { Пангу } \\
\text { Калевид } \\
\text { лик од древномекс. мит }\end{array}$ & $\begin{array}{l}\text { ламја } \\
\text { Тијамат } \\
\text { Вритра }\end{array}$ \\
\hline
\end{tabular}

Табела 2: Компаративна анализа на елементи и дејствија

\section{1. Ликови, нивни главни карактеристики и сфери на дејствување}

\subsection{1. Женски ликови транспонирани во космички елементи}

Ако тргнеме од тоа дека ламјата е женски митски лик, се воочува нејзиното совпаѓање со ликот на Тијамат кај кого е исто така јасно назначен женскиот пол, како и со божицата Атаениск и божицата од древномексиканскиот мит. Од друга страна, иако ликот на Имир не е од женски пол, женската компонента е кај него застапена преку јасно означените хермафродитни карактеристики на што, патем, укажува и етимологијата на неговото име. Не треба да се исклучи можноста такви карактеристики да поседувале и другите ликови, земајќи го предвид отсуството на јасно дефинирање на нивниот женски или машки пол.

\subsection{2. Влекачи (змијолики животни)}

Зад ликовите од балканските митски дејствија очевидно стојат змијолики суштества т.е. ламјата, алата или змијата (во примерот од Бугарија). Во прилог на тоа говорат и некои ликовни претстави во кои и Тијамат се прикажува како змија. Доколку ги споредиме иконите што го прикажуваат Св. Ѓор́́ со ламјата и ликовните претстави на борбата меѓу Мардук и Тијамат, очевидно е дека во двата случаи хероите се борат со влекачи. Змијолика природа има и индискиот Вритра, кој се претставувал како голем змеј, без раце и нозе. 


\subsection{3. Вода - долно ниво на вселената}

Во ликот на балканската ламја јасно се воочува нејзината поврзаност со водите, со земските сфери или со долните нивоа на вселената. Воедно таа се појавува и во улога на заробувач на водите, што всушност ќе доведе до нејзиниот судир со херојот. И Тијамат е симбол и персонализација на земските води кои постоеле на самиот почеток, пред создавањето на вселената. Генерално, женскиот принцип е поврзан со водата, со земското и со долните нивоа на вселената, поради што водниот карактер може да им се припише и на Атаениск, како и на божицата-чудовиште од древномексиканскиот мит.

\subsection{4. Симбол на хаосот, деструктивното и негативното}

Женските ликови од нашите дејствија можеме да ги определиме и како симболи на хаосот што е очевидно во однос на ламјата и Вритра, а особено на Тијамат, која, како божица на примордијалните води, го претставува целиот космос во неговата почетна (хаотична, неуредена) форма од кој подоцна ќе се создаде уредениот свет. Кога станува збор за негативните карактеристики на ламјата, нив можеме да ги воочиме кај Вритра, кој, покрај другото, се јавува и во улога на заробувач на водите.

\subsection{5. Џиновски размери}

Во народните претстави за ламјата се јасно изразени нејзините џиновски размери. Оваа карактеристика се воочува и кај најголемиот број од нејзините аналогии. Дури би можело да се каже дека, без разлика на тоа дали џиновската големина е експлицитно изразена или не, таа е воочлива во самиот факт дека телото на овие ликови е поистоветено со вселената, со оглед на тоа што таа всушност и се создава од нив. Бидејќ́ ова обележје важи за сите наши примери, него би можеле да го третираме како универзално. Тијамат е џиновски лик што го претставува целиот космос во неговата почетна форма. Џин е и кинескиот Пангу од чии очи се создаваат месечината и сонцето, од неговите рамена планините итн. Ова може да се забележи и во однос на Имир и Гаргантуа, кои се всушност џинови при што првиот е и праџин - првото суштество од кое потекнува сѐ. На оваа категорија припаѓа и Пуруша, кој е опишан како со своето тело целосно ја проникнува вселената. Ормазд го создава светот од своето тело кое растело во текот 
на долг временски период па кога пораснало доволно големо тоа ќе биде транспонирано во конкретните елементи на новосоздадениот свет.

\subsection{6. Мултиплицирани делови на телото}

Експлицитно изразени мултиплицирани делови на телото се присутни кај ламјата, која има повеќе глави (три, седум итн.), а тоа значи и мултиплицирани очи, усти, врат итн. Освен тоа ламјата има повеќ опашки, раце и крилја. Во однос на ова обележје, белезите на ламјата можат да се воочат и во ликовите на Пуруша и древномексиканската божица-чудовиште. Не се исклучува можноста мултиплицирани делови на телото да имал и Имир, бидејќи самото име етимолошки се поврзува со индоевропското *іето што може да значи двоен и близнак. Во овој случај кај посочениот лик се присутни двојно повеќе раце, нозе, очи и други делови на телото.

\section{2. Дејствија и елементи}

\subsection{1. Двобој со машки лик}

Во овие дејствија некои ликови се убиени од еден или повеќе машки ликови што е воедно заедничка карактеристика за сите нив. Некаде станува збор за двобој, во кој машкиот лик (демијург) го победува чудовиштето. Ваков двобој имаме кај ламјата спротивставена на Св. Ѓорѓ и, кај Тијамат како опонент на Мардук и на Вритра како опонент на Индра. Сличен е односот и кај останатите примери: Гајомард е убиен од Ариман (еквивалент на Сатаната); божицата-чудовиште е убиена од демијурзите - Близнаци; Имир е жртвуван од боговите Один, Вили и Ве.

\subsection{2. Поделување на два дела, распарчување}

Распарчувањето е екплицитно изразено во примерите со ламјата, Тијамат, Имир, Пуруша и божицата од древномексиканскиот мит. Ова дејствие му претходи на создавањето на светот од деловите од нивното тело. Освен што имаме распарчување, ликот на ламјата (поточно змијата од примерот од Бугарија) и Тијамат се поделени на два дела. 


\subsection{3. Транспонирање: глава (очи) - течности (езера, реки, потоци од други течности)}

Од главите на убиената ламја истекуваат реки т.е. потоци од корисни течности и тоа вино, млеко и масло. Во овие дејствија не е потенцирано од кој дел на главата тие истекуваат, што остава простор за толкување врз основа на аналогии. Од очите на Тијамат истекуваат реките Тигар и Еуфрат, а исто така и од многубројните очи на божицата од древномексикнскиот мит се создаваат реките. Од солзите на иранскиот Ормазд и на рускиот змеј се создаваат водите кои имплицитно треба да се идентификуваат со солзите затоа што истекуваат од очите. Во ваквото совпаѓање меѓу очите и водата се забележува и инверзна варијанта и тоа во чинот на создавање на првиот човек запишан во книгата на Енох. Таму, неговите очи се создадени од морето.

Сличностите во овој космогонски момент на прв поглед ќе ги забележиме во тоа што од ист или делумно ист дел на телото се создаваат различни реки или истекуваат реки т.е. струи од корисни течности кои секогаш имаат големо значење за човекот и тоа како симбол на благосостојбата. Реките Тигар и Еуфрат несомнено имале големо значење за луѓето во Вавилон, бидејќи го носеле животот и ја обезбедувале благосостојбата. Симбол на благосостојба можат да бидат и виното, млекото и маслото од нашите балкански примери.

\subsection{4. Транспонирање: стомак - води}

Посочената релација овој пат се однесува на другиот наш пример поврзан со настанувањето на водите на Охридското Езеро од стомакот на убиената ламја. ${ }^{14}$ Кај Вритра космичките води исто така истекуваат од неговиот стомак и тоа во облик на крави. Создавањето во насоката стомак - вода се забележува и кај Тијамат, чијашто една половина од телото се наоѓа долу. Притоа нејзиниот стомакот (т.е. средниот дел од телото) се поистоветува со водите, при пто тој е претставен и како граница меѓу горните (рајот) и долните (земски) нивоа на вселената.

\footnotetext{
${ }^{14}$ Според едно предание, Охридското Езеро е создадено од водата што истекува од распорениот стомак на ламјата (Милојковић 1985: 25, 26; Чаусидис 1994: 399-400).
} 


\subsection{5. Транспонирање: глава (коса) - растенија}

Ова дејствие се јавува кај поголем број примери каде што од главата и/или косата на чудовишниот лик излегуваат разни растенија: жито, дрвја, цвеќиња, трева итн. Станува збор за следните примери: кај ламјата - жито; кај Имир - дрвја; кај древноамериканскиот лик - дрвја, цвеќе, трева; кај Ормазд, Енох, Пангу и Калевид - растенија.

\section{Заклучок}

Во ова истражување се потрудивме да дадеме одреден придонес во реконструкцијата на варијантите на космогонискиот мит за настанокот на светот од телото на прасуштеството и тоа пред сѐ низ примери од територијата на Македонија. Тоа се разбира е една многу потесна, но не и помалку едноставна сфера.

Во основата на овој мит лежи феноменот на жртвувањето кое во најопшта смисла ахаичната свест го третира како трансмисија на елементи (или, во крајна смисла, на вредности) од една во друга сфера и тоа најчесто од микрокосмичката кон макрокосмичката. Преку жртвувањето се остварува космогонезата при што жртвата продолжува во некоја поинаква форма да егзистира и во новосоздадената вселена и нејзините конкретни елементи.

Според варијантите на овој мит присутни во светските митологии можеме да забележиме дека на еден глобален макрокосмички план во него се појавува прасуштеството од чие тело ќе биде повторно изграден универзумот. Ова суштество има надреални димензии, некогаш и надреални карактеристики, а притоа и карактер на панкосмичка жртва. Неговото тело се транспонира во новосоздадениот универзум при што самиот чин на негово жртвување добива значење на инвестирање од микрокосмичката кон макрокосмичката сфера. Со тоа и деловите на неговото тело кореспондираат со одредени делови од светот и тоа најчесто: очите со водите, косата со растенијата, коските со камењата и слично.

За универзалноста на овој мит сведочат примерите кои ги претставивме во првата глава. Овие примери се мошне различни, што секако се должи на тоа што припаѓаат на култури кои често ниту географски, ниту пак временски не егзистирале блиску една до друга. Нема секогаш ни совпаѓања на микрокосмичките и макрокосмичките елементи во овие примери, што ја потврдува нивната специфичност т.е. автентичност во однос на културата во која се создале. И покрај тоа, сите тие во својата основа го содржат космогонискиот мит за 
транспонирањето на делови од едно примордијално тело во елементите на универзумот.

Во реконструкцијата на овие аспекти се послуживме со примери од македонскиот фолклор и од фолклорот на регионите од нејзиното соседство, во кои е застапено сижето за убивањето и распарчувањето на некое чудовиште (змеј, ламја, аждер, јуда, самовила) од страна на јунакот - демијург. Во нив чудовиштето со демонски и хтонски карактеристики нанесува некаква штета (заробува води, луѓе, уништува посеви и сл.) поради што стапува во двобој со одреден светец или некој локален херој што е претставник на креативните сили (ред, светлина, живот). По убивањето, од телото на чудовиштето следува создавање на одредени елементи на светот т.е. природата (вода, растенија, жито, и други течности). Тие му носат благодат на човекот, при што нивното создавање воедно го означува и Новиот почеток или Новото време во кое хаосот е совладан, а светот се враќа во својата почетна состојба на уреденост и хармонија.

Во примерите од македонскиот фолклор уште еднаш ги истакнавме космогониските елементи, забележани и во некои досегашни истражувања, како и космичките обележја на ликовите околу кои се одвива главното дејствие. Пред сѐ тоа се убивањето на чудовиштето и повторното воспоставување на космичката рамнотежа, како и чинот на убивање и жртвување на чудовиштето, кој е поврзан со распарчувањето на sверот во основниот космогониски мит, со што се воспоставува новото време и новата животна сила. Во рамките на нашите истражувања направивме и анализа на ликовите во овие дејствија, што беше предуслов за преземање реконструкција на неговата изворна варијанта. Преку нив се покажа изедначеноста т.е. еквивалентноста на ламјата - со џиновски димензии како едно макрокосмичко обележје. Од другата страна се издвои ликот на светецот алтерниран со локалниот херој, обајцата во улога на спасители и претставници на позитивните и конструктивни сили.

Во постапката на интегрирање на елементите од нашите примери во структурата на основниот космогониски мит за прасуштеството се послуживме со компаративната анализа на ниво на ликовите, дејствијата и другите елементи содржани во македонските примери. Нив ги споредивме со соодветните аналогии од Балканот кои го сочинуваат вториот (поширок) круг на употребената граѓа, како и примерите од третиот кои не се временски и просторно ограничени. Компаративната анализа ни овозможи да ги воочиме остатоците на изворниот мит во дејствијата содржани во македонските примери.

На ниво на ликови потврдивме дека ламјатаво маке донскската граѓа има сличности со панкосмичките жртви од останатите при- 
мери. Нивната сличност се забележа во следниве карактеристики: женскиот или двојниот пол; демонолошките и хтонските карактеристики на овие суштества како владетели на водните и подземните површини и дивата природа; мултиплицираните делови на нивните тела (глави, крилја, опашки, раце и др.); џиновските размери и макрокосмичките карактеристики кои подразбираат вклучување на трите слоеви на универзумот во нивното тело. Освен тоа, во оваа компаративна анализа го воочивме и дефиниравме и присуството на митскиот херој во македонските примери. Без разлика дали станува збор за светецот или за локалниот херој, се покажа дека тој ги извршува истите дејствија и функции како демиурзите од останатите примери со што го потпомага или целосно го спроведува космогонискиот чин.

Во рамките на нашите анализи беа нотирани сличностите меѓу елементите и дејствијата од македонските примери и од оние содржани во граѓата од останатите балкански региони. Ги идентификувавме и идеалните парадигми на ламјата како жртвувано митско суштество од чии распарчени телесни делови ќе се создаде вселената. Се работи за добро познатите митски ликови и божества од древните култури кои за повеќе милениуми им претходат на македонските примери: Тијамат, Имир, Пуруша, Вритра и многу други. Совпаѓања забележавме и во релацијата микрокосмички - макрокосмички елементи, каде што генерално од горниот дел на телото (главата, очите, косите) и стомакот беа создадени водните површини и други течности и растенија.

\section{Библиографија}

АИФ - Архив на Институт за фолклор „Марко Цепенков“ - Скопје.

Анастасова-Шкрињариќ, Нина (2008). Митски координати. Скопје: Македонска Реч.

Анастасова-Шкрињариќ, Нина (2011). Фолклорни социјални фосили (социо-антрополошки студии за фолклорот). Скопје: Македоника литера.

Вражиновски, Танас (1995). Народната демонологија на Македонците. Прилеп: Институт за старословенска култура.

Вражиновски, Танас (1998). Народна митологија на Македонците. Кн. 1-2. Скопје: Матица Македонска.

Георгиева, Иваничка (1983). Българска народна митология. София: Наука и изкуство.

Зечевић, Слободан (1981). Митска бића српских предања. Београд: „Вук Караџић“, Етнографски музеј.

Иванов, Вяч, Топоров, Владимир Николаевич (1974). Исследования в области славянских древностей. Москва: Наука. 
Кюнстлер, М. (1987). Митология на Китай. София: Български художник.

Лафазановски, Ермис (2006). Легенда за ламјата од Охридското езеро: интерпретација на регионалната автентичност. Во Боне Величковски (ур.), Фолклорот во Охридско-Струшкиот регион. Скопје: Институт за фолклор „Марко Цепенков", 25-33.

Леон-Портилья, Мигелъ (1977). Мифологии древнего мира. Москва: Наука.

Луческа, Ели (2010). Како се градел култот на Свети Ѓорѓ во народната традиција на македонците. Балканославика 37-39, 126-138.

Мелетински, Елеазар Мойсеевич (2002). Поетика на митот. Скопје: Табернакул.

Миладиновци, Димитар и Константин (1962). Зборник 1861-1961. Скопје: Кочо Рацин.

Миладиновић, Михајло (1920). Народне песме из Маћедоније. Архив Српске академије наука и уметности, Београд, Етнографска збирка, бр. 262.

Милојковић, Мирко (1985). Легенде из наших крајева. Београд: Српска књижевна задруга.

Поповска-Коробар, Викторија (2008-2009) Охридско-струшки Иконописни траги од втората половина на XV век. Патримониум МК: Списание за културното наследство - споменици, реставрација, музеи 3, 289-302.

Раденковић, Љубинко (1982). Народне басме и бајања. Ниш: Градина; Приштина: Јединство; Крагујевац: Светлост.

СбНУ - Сборник за народни умотворения, наука и книжнина (1889-). София: МНП.

Стојановиќ-Лафазановска, Лидија (2001). Hoто Initiatus. Феноменот на иницијацијата во македонската народна книжевност. Скопје: Матица Македонска.

Тодоровић, Ивица (2011). Жељинска ала. Резултати нових истраживања народних митолошких представа Жупе. Гласник Етнографског института САНУ 59(2), 207-218.

Топоров, Владимир Николаевич (1992). Еще раз о фракийском всаднике в балканской и индоевропеискои перспективе. Образ мира в слове и ритуале. Балканские чтения I. Москва: Институт славяановедения и балканистики РАН.

Топоров, Владимир Николаевич (2001). Богови старих Словена. Во: Светлана М. Толстој, Љубинко Раденковић (ур.). Словенска митологија - енциклопедијски речник. Београд: Zepter Book World, 25-33.

Целакоски, Наум (1984). Дебарца, обреди, магии и обредни песни. Скопје: НИО, Студентски збор.

Црвенковска, Билјана (2004). Митски лавиринт. Скопје: Магор.

Чаусидис, Никос (1994). Митските слики на Јужните Словени. Скопје: Мисла.

Чаусидис, Никос (2005). Космолошки слики. Скопје: „Југореклам“.

Шапкарев, Кузман (1976). Избрани дела, 5 книги. Скопје: Мисла.

Andersen, Francis Ian (1983). Slavonic Apocalypse of Enoch. In: James Hamilton Charlesworth (Ed.). The Old Testament Pseudepigrapha, Vol. 1. London: Darton, Longman \& Todd., 91-222.

Brunet, Victor (1889). Gargantua en Basse-Normandie. Revue des Traditions Populaires IV. Paris, 472-473.

Eliade, Mirča (1991). Istorija verovanja i religijskih ideja, knj. I-III. Beograd: Prosveta. 
Geldner, Karl Friedrich (1951). Der Rig-Veda. Bd. 3. London \& Leipzig: Harvard University Press, Cambridge, Mass.

Hale, Mark (2008). Pahlavi. In: Woodard, Roger (Ed.) The Ancient Languages of Asia and the Americas. Cambridge: Cambridge Univerity Press, 123-135.

Jacobsen, Thorkild (1968). The Battle between Marduk and Tiamat. Journal of the American Oriental Society 88, 104-108.

Jensen, Adolf Ellegard (1939). Hainuwele. Volkserzdhlungen von der Molukkeninsel Ceram. Frankfurt: V. Klostermaml.

Kirby, William Forsell (1895). The Hero of Esthonia. Vol. 1. London: Forgotten Books.

Krim, Kit et al. (ur.) (2004). Enciklopedija živih religija. Prev. Lj. Miočinović et al. 2. fototipsko, dopunjeno izd. Beograd: Nolit, 2004.

Lambert, Wilfred George (2005). Akkadische Mythen und Epen. Enuma Elisch. In: Kaiser, Otto (Ed.) Texte aus der Umwelt des Alten Testaments, Vol. 3. Gütersloh: Mohn, 565-602.

Lajoye, Patrice. Purusa. Nouvelle Mythologie Comparée/New Comparative Mythologie. <http://nouvellemythologiecomparee.hautetfort.com/archive/2013/02/03/ patrice-lajoye-purusha.html> (30.5. 2018).

Lincoln, Bruce (1986). Myth, Cosmos, and Society. Indo-European Themes of Creation and Destruction. Cambridge: Harvard University.

Mall, Ram Adhar (1982). Indische Schöpfungsmythen. Eine Einführung. Bonn: Bouvier.

Pakzad, Fazlollah (2005). Bundahišn Zoroastrische Kosmogonie und Kosmologie, Bd. I. Tehran: Great Islamic Encyclopedia Foundation.

Rig Veda. <http://www.sacred-texts.com/hin/rigveda/rv10090.htm> (22.1. 2019).

Ross, Margaret Clunies (1994). Prolonged Echoes. Old Norse myths in medieval Northern society. Vol. I: The myths. Odense: Odense University Press.

Serafimova, Aneta (2008). St. George in Staro Nagoričane. In: Tričkovska, Julija (Ed.) Christian Monuments. Skopje: Ministry of Culture of the Republic of Macedonia Cultural Heritage Protection Office, 64-69.

Simek, Rudolf (2007). Die Edda. München: C. H. Beck.

Simrock, Karl (1876). Die Edda. Stuttgart: J. G. Cotta'schen Buchhandlung.

Williams, Alan Vincent (1990). The Pahlavi Rivāyat accompanying the Dadestan $i$ Denig. Copenhague: Historisk-filosofiske Meddelelser.

Zelenin, Dimitrij (1927). Russische (Ostslawische) Volkskunde. Berlin/Leipzig: de Gruyter \& Co. 


\title{
The Myth of World Creation from the Body of Primal Being - A Comparative Analysis, with an Emphasis on Macedonian Sources
}

\author{
Andzela Gruber
}

\section{Summary}

This type of creation myth appears in a vast number of cultures located at the various regions across the world, and is also dispersed across diverse historical periods. In the introductory part of the paper selected samples from world mythologies are being presented: Ymir, Purusha, Gayomard, etc. Traces of the myth have been recorded in folk literature, visual arts and ritualistic traditions of Macedonia, as well as in those of surrounding areas.

To reconstruct these aspects, we utilized cases from Macedonian folklore which employ storyline about hero-demiurge who kills and dismembers the monster - lamja (dragon). In the process of integration of the elements pertaining to our examples into the structure of basic creation myth of primal being, comparative analysis of characters, plot and other components has been applied. The analysis helped to discern the remnants of the original myth in plots of Macedonian specimens.

It has been confirmed, at the level of characters, that lamja from Macedonian sources shows resemblance to pancosmic sacrifice from other sources, sharing following traits: it is female or androgynous; has demonic features associated with the rulers of water or underground domains; has multiplied body parts, gigantic proportions and macrocosmic attributes implying that her body subsumes three layers of the universe. The presence of mythical heroes in Macedonian sources has been identified and determined. Regardless of whether they are saints or local heroes, it appears that the persona who executes acts and functions similar to demiurge in other sources supports or completely performs the act of cosmogony. Congruence has also been attested concerning the relation of microcosmic to macrocosmic elements: out of the upper body parts (head, eyes, hair) the water surfaces, fluids and overgrowth have been created.

It should be notified that this research is far from being exhausted. There is a vast array of sources in folklore tradition of Macedonia and neighbouring regions that could be, through results of similar analysis, included in a database we strived to establish.

Keywords: myth, cosmogony, creation myth, cosmogonic elements, Macedonian folklore, lamja, primal being, St. George, sacrifice 


\section{Der Mythos über die Entstehung der Welt aus dem Körper des Urwesens - eine komparative Analyse durch Hervorhebung Beispiele Mazedoniens}

Andzela Gruber

\section{Zusammenfassung}

Dieser Mythos ist in zahlreichen Kulturen anzutreffen, die in unterschiedlichen Regionen der Welt und unterschiedlichen Zeiträumen bestehen. Einige Beispiele aus der Mythologie weltweit haben wir am Anfang genannt: Ymir, Purusha, Gayomard usw. Spuren dieses Mythos sind bisher auch in der Volksliteratur, den künstlerischen Darstellungen und Ritualen in Mazedonien erschlossen worden. Bei der Rekonstruktion dieser Aspekte haben wir uns ein Beispiel aus der mazedonischen Folklore angeschaut, in welchem sich das Sujet über die Tötung und das Zerlegen eines Ungeheuers (des Drachen) vom Helden - Demiurg befindet.

Bei dem Integrieren der Einzelheiten unseres Beispiels in die Struktur des grundlegenden Mythos haben wir die komparative Analyse auf unterschiedlichen Ebenen eingesetzt: Ebene der Gestalten, Geschehen und anderer Elemente, die in unser Beispiel vorkommen. Dadurch hat sich die Möglichkeit ergeben die Reste dieses ursprünglichen grundlegenden Mythos in mazedonischer Handlung einzusehen.

Es hat sich auf der Ebene der Gestalten gezeigt, dass unser Drache und die pankosmischen Opfer viele Gemeinsamkeiten haben: das weibliche/das duale Geschlecht, ihre dämonischen Besonderheiten als Herrscher der Wasseroberflächen und der unterirdischen Oberflächen, die multiplizierten Körperteile, die Riesengröße, und die makrokosmischen Besonderheiten, die sich auf die drei in ihren Körpern auftretenden Schichten des Universums (Untergrund, Oberfläche und Himmel) beziehen. Außerdem kam auch der mythische Held in mazedonischer Handlung zur Einsicht. Egal ob er ein Heiliger oder ein lokaler Held ist, führt er die gleichen Aktionen des Demiurgen durch und damit fördert er teilweise oder im Ganzen den kosmogonischen Akt.

Übereinstimmungen sind auch im Verhältnis mikrokosmische - makrokosmische Elemente offensichtlich. Hier sind aus den oberen Teilen des Körpers (Kopf, Augen, Haare) allgemeinhin die Wasseroberfläche, andere Flüssigkeiten und Pflanzen entstanden.

Zum Schluss wollen wir auch hervorheben, dass unsere Leistung gar nicht abgeschlossen ist. In der mazedonischen Folklore und deren Umgebung befinden sich auch andere zahlreiche Beispiele, die wir mit Hilfe konformer Analyse zu dieser von uns etablierten Basis ergänzen könnten.

Schlüsselwörter: Mythos, Kosmogonie, kosmogonische Elemente, mazedonische Folklore, Drache, Urwesen, St. Georg, Opferung 


\title{
Мит о стварању света од тела прабића - компаративна анализа
} с нагласком на примерима из Македоније

\author{
Аниела Грубер
}

\section{Резиме}

Мит о стварању света од тела прабића се јавља у великом броју култура у разним географским регијама у свету, као и у разним историјским периодима. У уводном делу су представљени одабрани примери из светске митологије: Имир, Пуруша, Гајомард и др. Трагови овог мита су забележени у народној књижевности, ликовним представама и обредним традицијама на подручју Македоније, као и у њеном непосредном окружењу.

У реконструкцији ових аспеката послужили смо се примерима из македонског фолклора у којима је заступљен сиже о јунаку демијургу који убија и распарчава чудовиште - ламју. У поступку интегрисања елемената из наших примера у структуру основног космогонијског мита о прабићу послужили смо се компаративном анализом ликова, радње и других елемената садржаних у македонским примерима. Ова анализа је помогла да се уоче остаци изворног мита у радњи приказаној у македонским примерима.

На плану ликова потврдило се да ламја у македонској грађи има сличности с панкосмичким жртвама у осталим примерима, забележеним у следећим карактеристикама: женски или двојни пол; демонолошке карактеристике ових бића као владара водених и подземних површина; мултипликовани делови њихових тела, џиновске размере и макрокосмичке карактеристике које подразумевају укључивање три слоја универзума у њихово тело. Уочено је и дефинисано присуство митских хероја у македонским примерима. Независно од тога да ли је реч о свецима или локалним херојима, показало се да онај ко извршава исте радње и функције, као демијурзи у осталим примерима, потпомаже или у целини спроводи чин космогоније. Подударање је забележено и на релацији микрокосмички - макрокосмички елементи, кад су генерално од горњих делова тела (глава, очи, коса) биле саздане водене површине и друге течности и растиња.

Напомињемо да је наш рад далеко од завршеног. У фолклорној традицији Македоније и околним крајевима има још велики број других примера који, у сличним анализама, у наредном периоду могу да се укључе у базу коју смо покушали да успоставимо.

Кључне речи: мит, космогонија, космогонијски елементи, македонски фолклор, ламја, прабиће, Свети Ђорђе, жртвовање

\author{
Анџела Грубер \\ Институт за Фолклор „Марко Цепенков“, \\ Скопље, Северна Македонија \\ Е-пошта: andjelagruber@outlook.com
}

Примљено: 15. 8. 2020.

Прихваћено: 26. 12. 2020. 